\title{
From Aristotle to the Coalition of Immokalee Workers: Ethical competence via narrative ethics grows food justice
}

\author{
Review by Matthew J. Young*
}

Review of Food Justice and Narrative Ethics: Reading Stories for Ethical Awareness and Activism, by Beth A. Dixon. (2018). London: Bloomsbury. Available as hardcover and eBook; 192 pages. Publisher's website: https://www.bloomsbury.com/us/food-justice-and-narrative-ethics$\underline{9781350054561 /}$

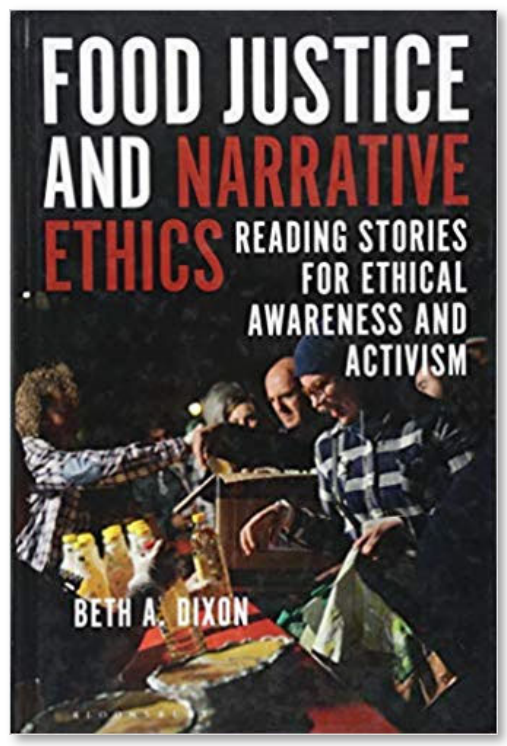

Submitted March 12, 2019 / Published online June 6, 2019

Citation: Young, M. J. (2019). From Aristotle to the Coalition of Immokalee Workers:

Ethical competence via narrative ethics grows food justice [Book review]. Journal of

Agriculture, Food Systems, and Community Development, 9(1), 131-133.

https://doi.org/10.5304/jafscd.2019.091.006

Copyright (C) 2019 by the Author. Published by the Lyson Center for Civic Agriculture and Food Systems. Open access under CC-BY license.

W hen conservationist Aldo Leopold wrote in the late 1940s about how one of the "penalties of an ecological education" includes "living alone in a world of wounds" (Leopold, Schwartz, \& Leopold, 1968, p. 197), he could have very well been foreseeing the challenges confronting food

* Matthew Young works as a bilingual social worker with the Minneapolis, Minnesota, nonprofit organization BeechWood Inc., and serves as an advocacy coordinator with the Minnesota Association for Environmental Education (MAEE) board of directors. He holds a bachelor's degree in Environmental Studies and English from St. Lawrence University and a master's degree in Environmental Studies with a concentration in Advocacy for Social Justice and Sustainability from Antioch University-New England. He currently lives in St. Paul, Minnesota, with his wife and University of Minnesota doctoral candidate, Florencia Pech Cardenas, and their preschool-age son, Mateo Antonio Young. He can be contacted at matteogiacomoyoung@gmail.com. systems advocates and food justice activists today.

Such advocates and activists become students of a probing moral education as they cultivate the targets of food justice in order to resolve myriad food injustices. State University of New York (SUNY) College at Plattsburgh philosophy professor Beth Dixon has written for years about how moral philosophy can greatly inform food justice theories and practices alike, including in her 2015 JAFSCD article, "Rewriting the Call to Charity: From Food Shelf Volunteer to Food Justice Advocate" (Dixon, 2015). Dixon's latest work, Food Justice and Narrative Ethics: Reading Stories for Ethical Awareness and Activism, guides the ethical novice (i.e., practically every food systems worker, food systems advocate, and food justice activist) on "learning to see what is unjust in a particular situation" via documentary films, ethnographies, 
and other food justice narrative-driven media. In turn, Dixon informs us about how we can "accurately identify what policies, laws, and structural conditions should change in order to discharge our responsibility for achieving social justice" (p. 3).

By the end of the introduction, Dixon has presented how narratives are a unique tool for illuminating "the ethically relevant circumstances that contextualize how individual people live as well as the background conditions that impede or constrain their actions" (p. 3). Dixon articulates that when food justice narratives fulfill conditions of particularity, accuracy, and emotional engagement during a "counterstory" - an alternative narrative that challenges the "socially-shared understanding" of a master narrative which "imposes a degrading identity on a person or a group, characterizing them as morally subnormal or abnormal" (p. 6) something particular happens. Dixon suggests that ethical novices (e.g., food justice advocates and activists) learn the particular skill of how to "read the situation" across food justice narratives. These practitioners can gain confidence in answering more nuanced questions of food justice that include, "What is the relation between misfortune and injustice? What events could have been avoided or mitigated? Who is the (collective or individual) agent responsible? And who is to blame?"

Dixon lays out a guiding view in the first and second chapters that invites the reader to consider ethical perception as "intimately connected to practical wisdom since one uses this kind of perception to grasp particulars necessary for a person to have practical wisdom as well as moral virtue" (p. 22). Refreshingly, Dixon does not shy away from sharing gems of insight from the timely yet timeless philosophy of Aristotle, including the Aristotelian view of what it means to "develop moral virtue by habituation." In other words, when a food justice advocate continually engages with how to think, feel, and act in morally apt ways, he or she is able to grow his or her abilities of "imagination, attention, empathy, critical reason, habit, exposure to new moral categories" (p. 24) when reading, viewing, and extracting what is morally important in a food justice narrative.
From the third through sixth chapters, Dixon deftly guides the reader through examples of how ethical novices can apply criteria of particularity, accuracy, and emotional engagement to flesh out lessons of ethical relevance. In Chapter 3, "Food Insecurity-Hungry Women," Dixon critiques how lofty standards of moral innocence presented among those who are food insecure, including among Feeding America website stories, can converge with a reliance on narrators who are morally unaware of systemic forces driving the poverty and oppression food-insecure individuals and populations face, as done on GlobalGiving's website. In Chapter 4, "Rewriting the Call to Charity," Dixon offers examples of Sankura Slamata of Burkina Faso and Rejeya Khatun of Bangladesh, two entrepreneurial women who cultivate greater access to nutritious food and community capital in their respective homelands with the support of the culturally conscientious, systemically aware organization The Hunger Project and affiliated entities. In Chapter 5, "Farmworkers: 'It Is Very Ugly Here," Dixon cites how the ethnography Fresh Fruit, Broken Bodies and the film Food Chains confront master narratives of illusory voluntary migration and unlimited individual moral agency around migrant farmworkers. They offer up counterstories of, respectively, Triqui indigenous migrants detailing departures from lifelong destitution in their native Mexico to Washington state due to free trade agreements, and of predominantly Latino tomato harvesters in Florida forming the Coalition of Immokalee Workers who launch a hunger strike in order to bring real human faces and grossly underpaid wages to the fore of a nebulous, oppressive food supply chain. In Chapter 6, "Obesity, Responsibility, and Situated Agency," Dixon illustrates how the protagonist Prager in the memoir Fat Boy, Thin Man and the three leading youth in the film Fed Up debunk master narratives of "false dichotomies" in moral responsibility among those experiencing obesity. This means, in Fat Boy, Thin Man, how addressing obesity means addressing behavioral and environmental changes, and in Fed Up how extending the scope of responsibility for obesity needs to include public policies and institutions and not isolate individuals from their economic, political, and societal surroundings. Thus, 
by the seventh chapter, "Practicing Philosophy," Dixon concludes her work by inviting ethical novices as food justice advocates to exercise blame as a moral protest in response to damaging master narratives and to "do something" in collective action for confronting injustice and oppression.

Ultimately, Food Justice and Narrative Ethics represents a critical, timely addition to the canon of food justice and the wider advocacy literature. Dixon's remarkable ability to synthesize academic theory across moral philosophy, alongside her own "eye for the particulars" in ethically salient details across a broad swath of food justice narrativefocused books and films, creates a compelling case for how and why moral philosophy needs to be included in future advocacy, food systems, government, political science, and sociology curricula.
Food Justice and Narrative Ethics leaves the reader empowered to know that the act of writing and telling counterstories, which are capable of "shaping our moral imaginations about what is possible" (p. 89), provides an invaluable step in positioning us as food justice advocates to take responsibility for making a healthier, more equitable, more just, and more morally accountable future in meeting the timeless need for access to healthy food. From documenting how Aristotle wrote about ethical competence to detailing how the Coalition of Immokalee Workers has left its mark on food justice activism, Dixon's work charges us with the purpose of cultivating responsibility but also cultivating hope and optimism throughout the ages-long causes of providing food for all and justice for all.

\section{References}

Dixon, B. A. (2015). Rewriting the call to charity: From food shelf volunteer to food justice advocate. Journal of Agriculture, Food Systems, and Community Development, 5(2), 71-79. https://doi.org/10.5304/jafscd.2015.052.010

Leopold, A., Schwartz, C. W., \& Leopold, A. (1968). A Sand County Almanac and Sketches From Here and There. London: Oxford University Press. 